\title{
八角形中空断面部材の塑性変形性能評価 EVALUATION OF PLASTIC DEFORMATION CAPACITY OF OCTAGONAL HOLLOW CROSS-SECTION MEMBER
}

\author{
五十嵐 規矩夫*1, 八馬 秀*2 \\ Kikuo IKARASHI and Shu HACHIUMA
}

\begin{abstract}
When the shape of the cross-section is changed from a square to an octagon by chamfering the four corners of the square, the octagonal hollow cross-section is not only permited the use of thin plate elements, but also suppressed local buckling. But there are few studies addressing octagonal members, and it is not sufficiently clear whether and how the cross-sectional shape affects their buckling behavior. This study aims to show how the cross-sectional shape affects elastic buckling strength and suggests a method to evaluate maximam strength and plastic deformation capacity of octagonal hollow cross-section member.
\end{abstract}

Keywords : Octagonal hollow cross-section, Plate local buckling, Finite element method, Loading test, Width-thickness ratio, Plastic deformation capacity 八角形中空断面，局部座屈，有限要素法，載荷実験，幅厚比，塑性変形性能

1. 序

一般に鋼構造建築物の柱材として用いられている正方形中空断面 部材の大変形挙動には局部座屈が影響を与えることが知られており, 局部座屈は板要素の幅厚比が大きいほど起こりやすい. また, 経済 的かつ施工しやすい構造を実現するためには，部材に使用する鋼材 料を減らすことが要求される. これらの要求に同時に応える部材と して八角形中空断面部材が期待される.八角形中空断面部材は元の 正方形断面から角を削ぐことで板要素の幅が小さくなり, 同じ板厚 では結果的に幅厚比も小さくなるためである.

八角形中空断面部材と同様に，板要素で構成されている閉断面部 材の研究として, 正方形中空断面部材の研究1) 3)がある. 佐藤ら ${ }^{1) 21}$ は二軸曲げせん断力と軸力を受ける正方形中空断面部材の弾性局部 座屈耐力をエネルギー法による座屈解析を用いて導出した後, 実条 件考慮型指標である新規幅厚比尺度を用いて正方形中空断面部材の 最大耐力と塑性変形能力を評価している. 三井ら 受ける正方形中空断面部材の塑性変形能力を, 局部座屈の影響のみ ならず全体座屈の影響がある部材形状を対象に実大実験を行うこと で確認している.

八角形中空断面部材に関する既往の研究としては文献4) 7)があ る. 小瀬古ら ${ }^{4}$ は八角形中空断面部材について実験と解析によりそ の座屈耐力を検討している. また八角形中空断面の近似残留応力度 分布をモデル化し，その応力度分布を用いて部材の非弾性固有值解 析を行い, 実験值が計算值より高いと指摘している. 右田ら ${ }^{5)}$ による 4から8角形を持つ正多角形中空断面部材についての研究では, 短柱
圧縮試験により部材の最大耐力は構成板要素の幅厚比によって変化 することを示した上で耐力評価式の提案を行なっている．Ahmed ら ${ }^{0}$ は幅厚比の異なる $8,12,16$ 角形断面部材に対し短柱圧縮試験を 行なっている. その結果, 座屈耐力は断面の角数によらず板要素の 幅厚比が決定要因となることを示している．また同じ断面積を持つ 多角形断面であれば，幅厚比が小さいほど座屈耐力が大きくなるこ とを示している. 小橋ら ${ }^{7}$ は薄肉軽量形構造を想定した八角形中空 断面部材に対し, 短柱圧縮の荷重条件で実験と解析を行なっている. 角を削ぐ幅によって八角形断面の座屈傾向は変化することを示し， 軸圧縮力のみを受ける八角形中空断面部材の最大耐力は断面を構成 する板要素を，回転支持を受ける平板とみなすことで評価可能であ ることを示している.

このように八角形中空断面部材を扱った研究の例はあるものの, 基本的な性状を検討したものがほとんどである．曲げせん断の荷重 条件の下，角を削ぐ前の断面の幅厚比が角形鋼管の幅厚比制限值 ${ }^{8)}$ よりも小さい部材に対しパラメトリックな検討を行ったものはなく, その断面形状が局部座屈性状に与える影響について十分に明らかに なっているとは言い難い，また，このような断面を持つ部材の塑性 変形性能の評価方法は存在しない.

そこで本研究ではまず，圧縮または曲げが作用する八角形中空断 面部材に対して, 有限要素法による固有值解析を行うことで削ぎ幅 を変化させた八角形中空断面部材の板座屈係数を求め, 圧縮または 曲げが作用する八角形中空断面部材の座屈係数評価式を提案してい る.また同様に削ぎ幅を変化させた八角形中空断面部材に対して軸
*1 東京工業大学環境 · 社会理工学院建築学系 教授 ·博士 (工学)

*2 東京工業大学環境・社会理工学院建築学系 大学院生 
力および曲げせん断力を受ける片持ち柱形式の大変形解析を行うこ とで, 八角形中空断面部材の塑性変形性能を確認している. 比較の 際には材長が大変形挙動に与える影響を検討した上で, 同じ平板部 の幅厚比を持つ正方形中空断面部材を用いて塑性変形性能を検討し ている. 次に, 初期不整量の最大值が塑性変形性能に及ぼす影響を 検討するため, 初期不整量の最大值をパラメータとして大変形解析 を行なっている. また, 八角形中空断面部材の実挙動を把握するた めに片持ち梁形式の曲げせん断試験を行い, 八角形中空断面部材の 塑性変形性能を確認し, 全幅および部材長が等しい正方形中空断面 部材の塑性変形性能と比較している. 最後に文献2)によって提案さ れている正方形中空断面部材に対する新規幅厚比尺度に対して, 本 研究により得られた八角形中空断面部材の座屈係数評価式を適用し, あわせて提案されている正方形中空断面部材の新規幅厚比尺度を用 いた塑性変形性能評価式によって, 大変形解析および載荷実験によ り得られた八角形中空断面部材の塑性変形性能が評価可能であるか を検討している.この際初期不整が正方形および八角形中空断面部 材の塑性変形性能に与える影響を考慮している.

\section{2. 純圧縮または曲げを受ける八角形中空断面部材の弾性座屈係数}

Fig.1に本研究で用いる数值解析モデルを示す.八角形中空断面は 全幅 $D$ の正方形断面の角部を削ぎ，その削ぎ幅 $W$ を断面形状が正八 角形となるまで変化させたものを検討する. 角を削ぎ, 全幅から残 った部分を平板部とする. 座屈固有值解析においてFig.1(b),(c)に示 すように部材両端に純圧縮または曲げモーメントを作用させ，曲げ の場合は曲げモーメント勾配 $\beta$ を変化させた場合を検討した。

\section{1 純圧縮を受ける八角形中空断面部材の弾性座屈係数}

まず，純圧縮作用時の座屈係数評価式との対応を確認する. 式 (2.1)に文献9)で提案されている純圧縮作用時での座屈係数評価式を 示す. 文献9)では薄肉断面部材を想定している. そのため本研究で はより板厚が厚い $1.6 \mathrm{~mm} 4.5 \mathrm{~mm}$ の範囲において文献 9 )における提
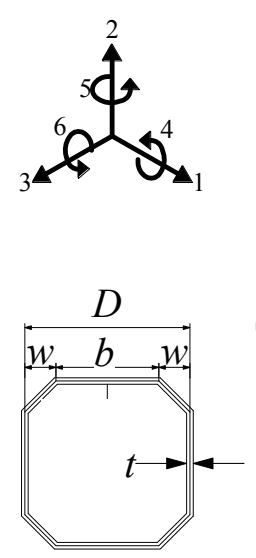

(a) Cross Section

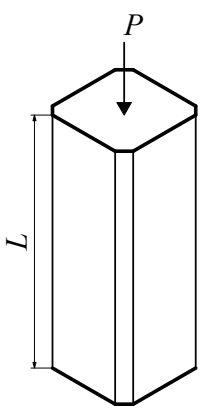

(b) Compression Model

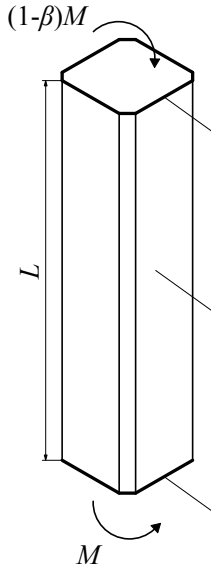

(c) Bending Moment Model
Rigid elements 4-node shell elements

Rigid elements

\begin{tabular}{|c|c|c|c|}
\hline & Fixed Rotation & & Fixed Rotation \\
\hline Upper End & $1,3,4,5,6$ & Upper End & $1,3,4,5$ \\
\hline Lower End & $1,2,3,4,5,6$ & Lower End & $1,2,3,4,5$ \\
\hline
\end{tabular}

Fig.1 Finite Element Model
案式が利用できるかを検討する.

式(2.1)は平板部が角を削いだ部分により回転拘束を受けること を想定し求められた近似式 9 である。

$$
{ }_{c} k_{r c r}=4 \gamma+6.98(1-\gamma)
$$

ここで $\gamma$ いいて次のように与えられている.

$$
\begin{cases}\gamma=4.6 \frac{\sqrt{2} w}{b} & \left(0.0<\frac{\sqrt{2} w}{b} \leq 0.1\right) \\ \gamma=0.4+0.6 \frac{\sqrt{2} w}{b} & \left(0.1<\frac{\sqrt{2} w}{b} \leq 1.0\right)\end{cases}
$$

式(2.3)は八角形断面がFig.2に示すように八角形中空断面の一部 が波板平板で構成されていると考え，直行異方性平板の座屈式 ${ }^{(0)}$ 用いて構成している. なお強, 弱軸周りのポアソン比は $v_{x}=v_{y}=0$ としている

$$
{ }_{c} k_{d c r}=\frac{\frac{2}{t}\left(\frac{\pi}{b+w}\right)^{2}\left(D_{x y}+\sqrt{D_{x} D_{y}}\right)}{\frac{\pi^{2} E}{12\left(1-v^{2}\right)}\left(\frac{t}{b}\right)^{2}}
$$

ここで, $D_{\mathrm{x}}, D_{\mathrm{y}}$ : 平板の強, 弱軸回りの曲げ剛性, $D_{\mathrm{xy}}$ : 平板のせん 断剛性, $E$ : ヤング係数, $v$ : ポアソン比である.

また, 本研究では全幅 $D$ を持つ正方形中空断面部材に純圧縮が作 用する場合の座屈係数である式(2.4)を下限值として考える.

$$
{ }_{c} k_{a c r}=\frac{4.0 \frac{\pi^{2} E}{12\left(1-v^{2}\right)}\left(\frac{t}{D}\right)^{2}}{\frac{\pi^{2} E}{12\left(1-v^{2}\right)}\left(\frac{t}{b}\right)^{2}}
$$

以上の式を用いて式(2.5)の条件から純圧縮を受ける八角形中空 断面部材の座屈係数を評価する.

$$
{ }_{c} k_{\mathrm{cr}}=\max \left\{{ }_{c} k_{\mathrm{acr}},{ }_{c} k_{d c r}\right\} \text { and } \min \left\{{ }_{c} k_{d c r},{ }_{c} k_{r c r}\right\}
$$

Fig.3に評価式と解析值との対応を示す. 縦軸は固有值解析から 求めた八角形中空断面部材の座屈係数を正方形中空断面部材の純圧 縮作用時の座屈係数を示寸式(2.6)で除した座屈係数比である.

$$
{ }_{c} k_{s q}=4.0
$$

横軸は角部削ぎ幅 $W$ を全幅 $D$ で除した削ぎ率である.式(2.1)が破 線，式(2.3)が実線，式(2.4)が点線であり，式(2.3)のみ板厚により変 化する. 3 つ式を利用した式(2.5)によって座屈係数を概数評価で きていると言える。
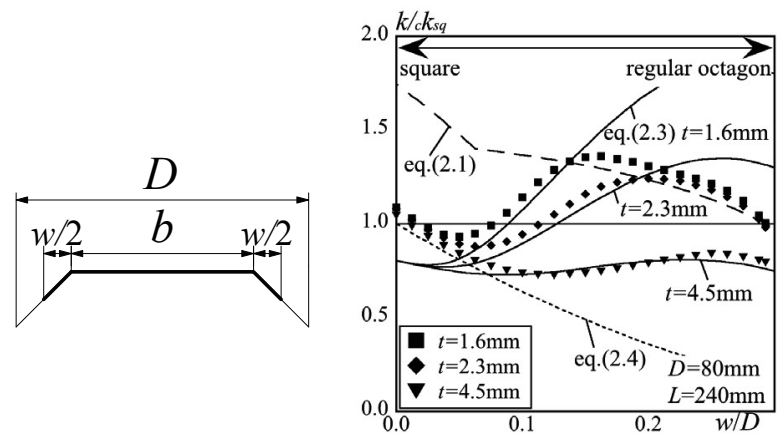

Fig.2 Range of Thinking as Corrugated Plate
Fig.3 Correspondence of Evaluation Formula 


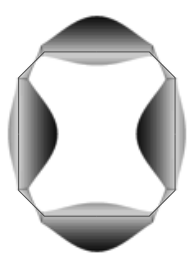

(a) $t=2.3$ $W / D=0.15$

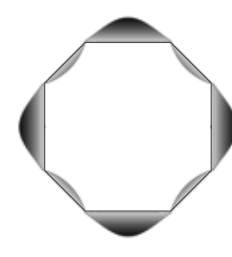

(b) $t=2.3$

$w / D=0.25$

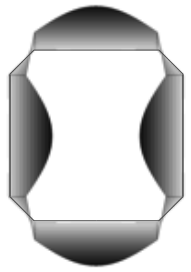

(c) $t=4.5$

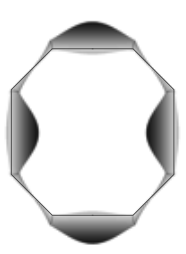

(d) $t=4.5$
Fig.4 Waveform of Buckling Octagonal Member

Fig.4に板厚および削ぎ幅と座屈モードの対応を示す. Fig.4(b)の ような板要素の稜線を基準として板要素に交互に波形が現れる座屈 モードが現れる場合は式(2.1)で評価される範囲にあり，Fig.4(a)，(c)， (d)のように板同士が接合される稜線が移動し, 角を削いだ部分がゆ がむ座屈モードの場合には式(2.3)で評価される範囲にある.

\section{2 曲げを受ける八角形中空断面部材の弾性座屈係数}

次に曲げを受ける八角形中空断面部材の座屈係数評価式を検討す る. Fig.5(a)に曲げモーメント勾配 $\beta$ にる座屈係数の変化を示寸. 縦軸は解析值を文献1)で提案される曲げを受ける正方形中空断面部 材の座屈係数評価式(2.7)で除した座屈係数比である.

$$
{ }_{b} k_{s q}=5.6\left(1+1.7 \frac{\beta}{(L / b)}\right)
$$

横軸は削ぎ幅 $W$ 全幅 $D$ で除した削ぎ率である. 図より同じ板厚で あれば, 座屈係数は, 曲げモーメント勾配 $\beta$ にらず同一の ${ }^{2} / D$ で等 しい值となる. そこで, 式 $(2.7)$ が定数となる均等曲げ $(\beta=0)$ の場合を 考える.

本節で提案する座屈係数評価式はその定数を八角形中空断面に適 応するための $k$ を用いた式(2.8)とする.

$$
{ }_{b} k_{c r}=\bar{k}\left(1+1.7 \frac{\beta}{(L / b)}\right)
$$

また $\bar{k}$ は三個の式から表される.まず，式(2.9)は文献7)で提案 されているもので，平板部が角を削いだ部分により回転拘束を受け ることを想定し求められた近似式である.

$$
{ }_{b} k_{r c r}=4 \gamma+6.98(1-\gamma)
$$

ここで $/$ ついて次のように与えられている.

$$
\begin{cases}\gamma=4.6 \alpha \frac{\sqrt{2} w}{b} \quad & \left(0.0<\frac{\sqrt{2} w}{b} \leq \frac{0.1}{\alpha}\right) \\ \gamma=0.4+0.6 \alpha \frac{\sqrt{2} w}{b} & \left(\frac{0.1}{\alpha}<\frac{\sqrt{2} w}{b} \leq \frac{1.0}{\alpha}\right) \\ \gamma=1.0 \quad & \left(\frac{1.0}{\alpha}<\frac{\sqrt{2} w}{b}\right) \\ \alpha=0.7+0.3 \frac{1}{\left(1+2 \frac{w}{b}\right)}\end{cases}
$$

次に, 式(2.12)は式(2.3) と同様に八角形中空断面が4つの波板平 板で構成されていると考え, 純圧縮のかかる八角形中空断面部材の 座屈係数評価式に利用した直行異方性平板の座屈耐力評価式 ${ }^{10)}$ から 近似的に求めた式である.

$$
{ }_{b} k_{d c r}={ }_{c} k_{d c r} \frac{1}{\left(1+\frac{w}{b+w}\right)}+1.6
$$

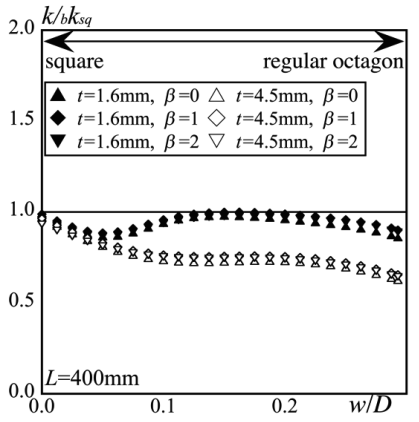

(a) Effect of $\beta$ on buckling coefficient

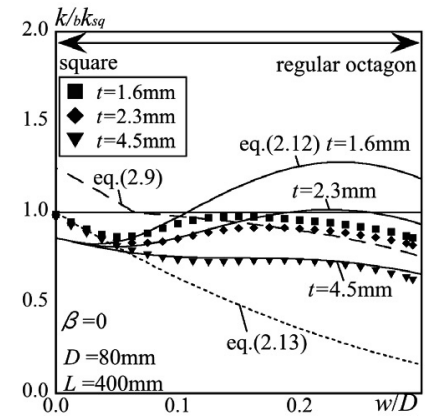

(b) Correspondence of equation
Fig. 5 Relation between buckling coefficient and $w$

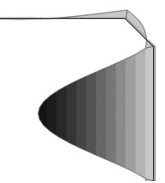

(a) $t=2.3$ $w / D=0.15$

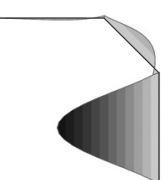

(b) $t=2.3$ $w / D=0.25$

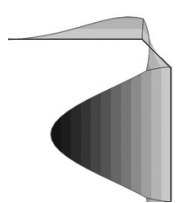

(c) $t=4.5$ $w / D=0.15$

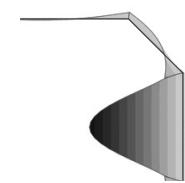

(d) $t=4.5$ $w / D=0.25$
Fig.6 Waveform of Buckling Octagonal Member

また, 本研究では全幅 $D$ を持つ正方形中空断面部材に曲げが作用 する場合の座屈係数1)である式(2.13)を下限值として考える.

$$
{ }_{b} k_{a c r}=\frac{5.6 \frac{\pi^{2} E}{12\left(1-v^{2}\right)}\left(\frac{t}{D}\right)^{2}}{\frac{\pi^{2} E}{12\left(1-v^{2}\right)}\left(\frac{t}{b}\right)^{2}}
$$

以上の(2.9)，(2.12)，(2.13)式を用いて式(2.14)を，曲げを受ける 八角形中空断面部材の座屈係数評価式として提案する.

$$
\bar{k}=\max \left\{{ }_{b} k_{a c r},{ }_{b} k_{d c r}\right\} \text { and } \min \left\{{ }_{b} k_{d c r},{ }_{b} k_{r c r}\right\}
$$

Fig.5(b)に提案式と解析值との対応を示す. 式(2.9)が破線, 式 (2.12)が実線，式(2.13)が点線であり，式(2.12)のみ ${ }_{c} k_{d c r}$ の関係から板 厚により変化する. 3つの式を利用した式(2.14)を用いることにより どの板厚においても提案式で座屈係数を概ね評価できていると言え る.また板厚および削ぎ幅と座屈モード(右上半分のみ表示)の対応 を見ると, Fig.6(b)のような板要素の稜線を基準として板要素に交 互に波形が出る座屈モードの場合には式(2.8)で評価される範囲に あり，Fig.6(a)，(c)，(d)のような稜線が移動し，角を削いだ部分がゆ がむ座屈モードの場合には式(2.9)で評価される範囲にある.

\section{3. 軸力および曲げせん断力を受ける八角形中空断面部材の大変形 挙動}

\section{1 曲げせん断カを受ける八角形中空断面部材の大変形挙動}

八角形中空断面部材の塑性変形性能を大変形解析によって検討寸 る. 本章での検討に用いる解析の概要をFig.7に示す。また初期不 整として一次の座屈モードの最大值を板厚 $t$ の $1 / 10$ となるように設 定し大変形解析を行っている. 荷重条件は一端固定他端自由として いる. 付録Aに4章でおこなう載荷実験と本数值解析との対応を示し ている. 両者は良く一致しており，解析の妥当性が示されている.

まず，八角形中空断面部材の塑性変形性能に与える材長の影響を 検討する. 材長は板幅bによらず $L=400 \mathrm{~mm}$ で一定值を用いるものと， 
板幅bに比例して変化する材長 1 を用いるもの同士で比較するために, Fig.8に示すような 3 種類の検討を行う. Fig.8(a)の検討1は各々の部 材のせん断スパン比を 5 としたものである.この場合同じ幅 $b$ を持つ 八角形中空断面と正方形中空断面で全幅辺長比が等しくなり, 平板 部幅が変化しても辺長比は変化しない. Fig.8(b)の検討2は断面の変 化によらず材長が一定となる検討である。この場合同じ幅 $b$ を持つ 八角形中空断面と正方形中空断面で平板部辺長比が等しくなり, 平 板部幅が小さくなれば辺長比は大きくなる. Fig.8(c)の検討3は八角 形中空断面の平板部辺長比を $l / b=5$ で一定としたものである.この場 合平板部幅 $b$ 小さくなるに従って材長 $l$ も小さくなる.これらの検 討で得られた最大耐力と塑性変形倍率を比較した。この比較では板 厚を $t=2.3 \mathrm{~mm}$ とし，軸力が作用しない場合を検討している.

Fig.9に検討1, Fig.10に検討2, Fig.11に検討3の解析結果を示寸. それぞれの(a)は最大耐力を全塑性モーメントで除したもの，Fig.9， Fig.10に塑性変形倍率, Fig.11(b)にせん断スパン比を示す. どの図 も横軸は平板部幅厚比であり, 黒プロットが八角形断面, 白プロッ トが正方形中空断面の結果を表す。八角形中空断面は角を削ぐ幅 $W$ が大きくなると平板部幅bは小さくなる.これにより $W$ を変化させる と幅厚比 $b / t$ も変化する。

検討1では(a)最大耐力, (b)塑性変形倍率共に幅厚比が小さくなる につれ両部材の值が上昇するが，八角形中空断面の上昇率は正方形 中空断面のものよりも小さい. 検討 2 では(a)最大耐力, (b) 塑性変形 倍率共に八角形中空断面と正方形中空断面の值は検討 1 に比較して 概衩一致している. 八角形中空断面の最大耐力, 塑性変形倍率はそ の平板部の持つ幅厚比, 辺長比と等しい正方形断面として評価でき

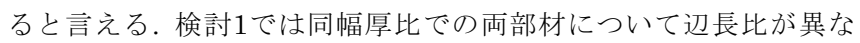
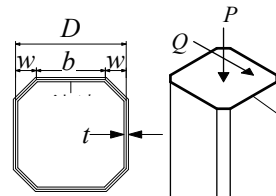

Rigid elements
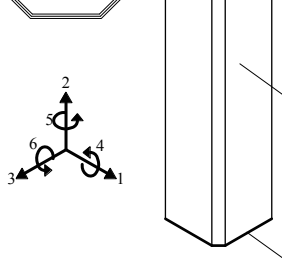

4-node

shell elements

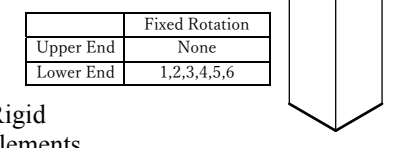

(a) Octagonal Member

(b) Square Member

Fig.7 Finite Element Model Under Bending Shear Force and Compression Force

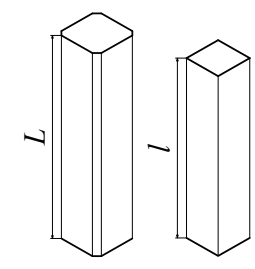

(a) Consideration

No. 1 $L / D=I / b=5$
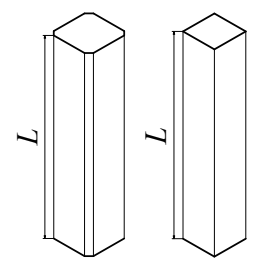

(b) Consideration No. 2 $L=400 \mathrm{~mm}(L / D=5)$

Fig. 8 Consideration of Length
るため值が一致しなかったと考えられる。また，検討 1 , 検討 2 はど ちらも(a), (b)共に幅厚比が小さくなるにつれ八角形中空断面の值が 上昇している，角を削ぐ幅Wを大きく寸ることにより最大耐力, 塑 性変形倍率は上昇寸ると言える．また $b / t=25$ 近傍で八角形中空断面 部材の塑性変形倍率が正方形中空断面部材のものを上回っている要 因としては， $b / t=25$ 近傍以外の八角形中空断面部材と任意の幅厚比 の正方形中空断面部材の座屈モードが圧縮側平板において内側に凸 となっている一方で, $b / t=25$ 近傍の八角形中空断面部材の座屈モー ドは圧縮側平板において外側に凸となっていることによるものであ ると考えられる．検討 3 では幅厚比が 25 よりも小さくなると八角形 中空断面の最大耐力の上昇率が正方形断面よりも小さくなる．この 時, 図は省略するが検討 1 と同様に塑性変形倍率の上昇率も小さく なっていた。これは，平板部幅が小さくなるに従い材長も小さくな る一方, 全幅は一定であるため部材のせん断スパン比が小さくなり, せん断力の影響を無視できなくなったためであると考えられる.

Fig.11(b)から幅厚比が25の時のせん断スパン比はおよそ3.0である ことから, 八角形中空断面のせん断スパン比を 3.0 以上確保すること で幅厚比，辺長比が等しい正方形中空断面と最大耐力は概ね一致す

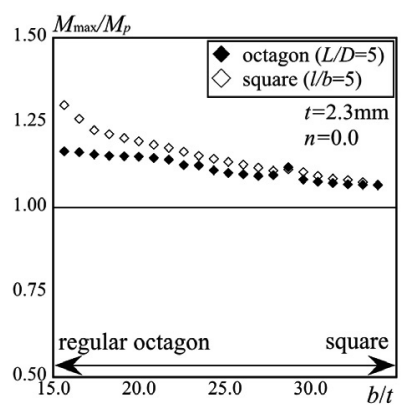

(a) Maximum Strength

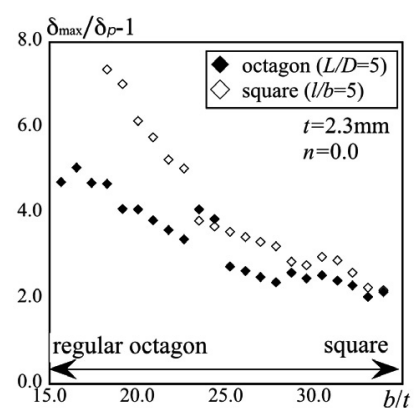

(b) Plastic Deformation Capacity
Fig.9 Result of Consideration No.1

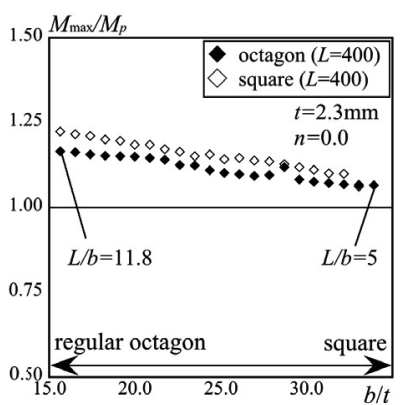

(a) Maximum Strength

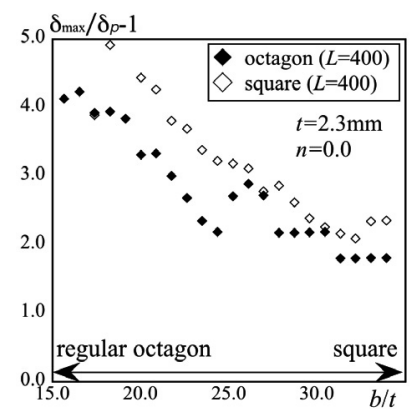

(b) Plastic Deformation Capacity
Fig.10 Result of Consideration No.2

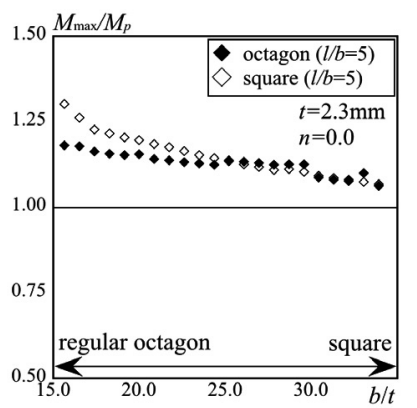

(a) Maximum Strength

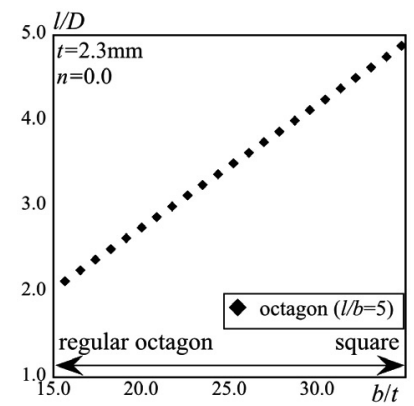

(b) Shear Span Ratio

Fig.11 Result of Consideration No.3 
ると言える

\section{2 軸力および曲げせん断力を受ける八角形中空断面部材の塑性 変形性能}

材長を固定することにより八角形中空断面の平板部の辺長比と正 方形断面の辺長比を一致させた検討 2 にいて両部材の最大耐力と 塑性変形倍率の值が概ね一致した。 そこで，本節では両部材の材長 を一定 $L=400 \mathrm{~mm}$ とした解析を行う．軸力を作用させる際には， 各々の部材の断面積と降伏応力度から導出し, $n=0.1 \sim 0.3$ の範囲で 検討を行った. ここで, 軸力比 $n$ は作用軸力 $P$, 断面積 $A$, 降伏応力 度 $\sigma_{\mathrm{y}}$ を用いて式(3.1)で表される.

$$
n=P /\left(A \cdot \sigma_{\mathrm{y}}\right)
$$

まず，Fig.12に軸力が作用しない場合の八角形中空断面と正方形 中空断面の荷重変位関係の比較を示寸. 実線が八角形中空断面，点 線が正方形中空断面である．どの場合においても両部材の平板部幅 厚比が等しい場合, 最大耐力, 変形能力は概ね一致している.この ように, 材長を固定し両部材の辺長比 $L / D$ を一致させることで平板 部幅厚比の等しい両部材の荷重変位関係も概水一致する.

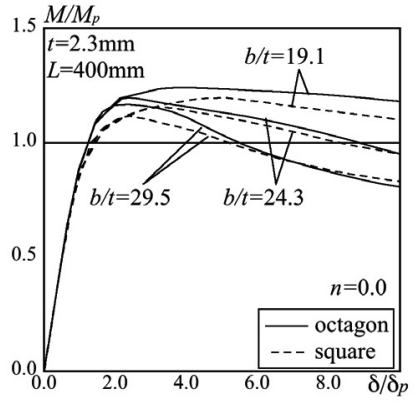

Fig.12 Comparison between Same b/t Ratio on Deformation Behavior

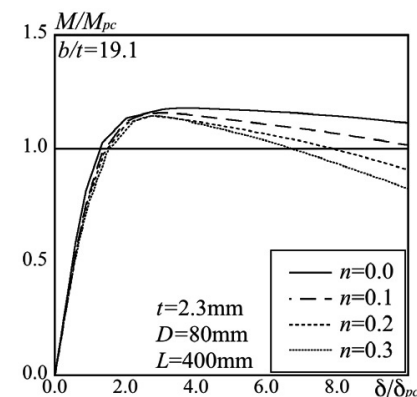

Fig.13 Effect of Compression Force on Deformation Behavior

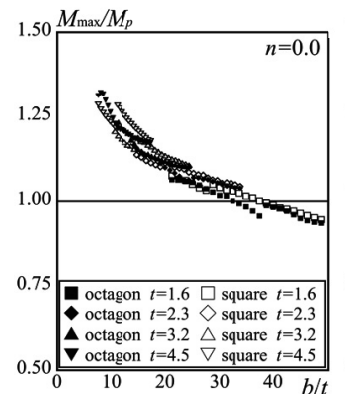

(a) $n=0.0$

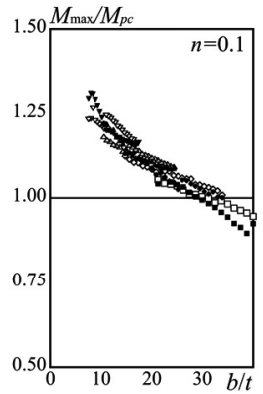

(b) $n=0.1$

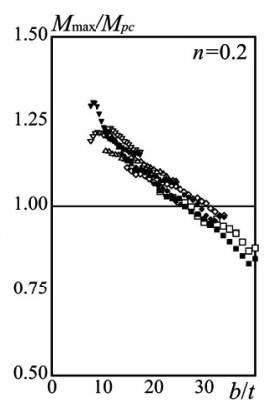

(c) $n=0.2$
Fig.14 Effect of Compression force on Maximum Strength

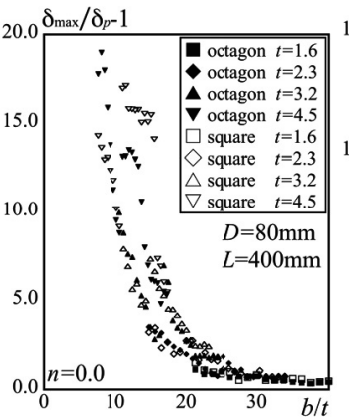

(a) $n=0.0$

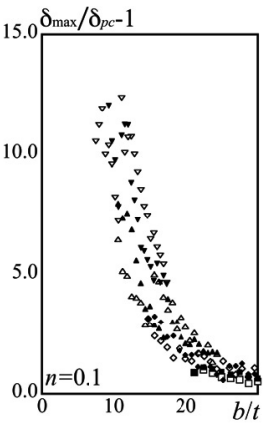

(b) $n=0.1$

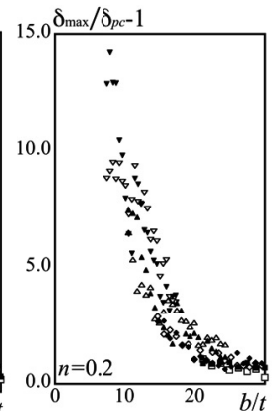

(c) $n=0.2$
Fig.15 Effect of Compression force on Plastic Deformation Capacity
Fig.13に同じ幅厚比を持つ八角形中空断面部材において軸力比の みを変化させた場合の荷重変位関係を示寸。縦軸，横軸はそれぞれ 軸力の影響を考慮した全塑性モーメント $M_{p c}$, 全塑性モーメント相 当弾性変位 $\delta_{p c}$ で除している. $M_{p c}, \delta_{p c}$ を用いることにより最大耐力, 最大耐力時変位は軸力の影響によらず概ね一定である。また，以上 の傾向は幅厚比 $b / t=15 \sim 35$ の範囲でも確認された。ただし，最大耐 力到達以降は軸力の影響を受ける.

断面の板厚や軸力比を変化させた場合についても大変形解析結果 を整理した. Fig.14は最大耐力, Fig.15は塑性変形倍率を示している 同じ軸力比において幅厚比の等しい八角形中空断面と正方形中空断 面の最大耐力と塑性変形倍率の值は概敉一致している。この傾向は 板厚を $1.6 \mathrm{~mm} \sim 4.5 \mathrm{~mm}$ ，軸力比を $0.0 \sim 0.3$ で変化させた場合でも表れ た。これらの結果から板厚が変化した場合，軸力の作用した場合で も八角形中空断面の最大耐力, 塑性変形能力はその平板部の幅厚比, 辺長比と等しい正方形中空断面として評価できると言える.

\section{3 初期不整が八角形中空断面部材の塑性変形性能に及ぼす影響}

初期不整が八角形中空断面部材の塑性変形性能に与える影響を検 討する. 前節では初期不整の最大值を板厚 $t$ の $1 / 10$ として解析を行っ たが，文献2)では正方形中空断面部材に対し初期不整の最大值を前 節での検討よりも小さい板幅 $b$ の $1 / 2000$ として解析を行い，評価式 を提案しているため，その違いを検討する必要がある. Fig.16に初 期不整の最大值 $i[\mathrm{~mm}]$ と最大耐力, 塑性変形倍率の関係を示す. 黒のプロットの八角形中空断面に対し, その平板部と幅厚比，辺長 比が等しい正方形中空断面は同じ形の白のプロットで表している. また，図内の上部には，iを板厚 $t$ $1 / 10$ とした場合，板幅 $b$ $1 / 2000$ とした場合のおおよその範囲を示す，そして，文献11)によると正方

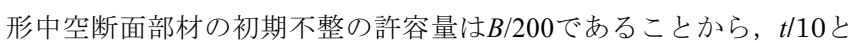
いう初期不整量は $B / t=20$ 以上で許容量となる初期不整量である.

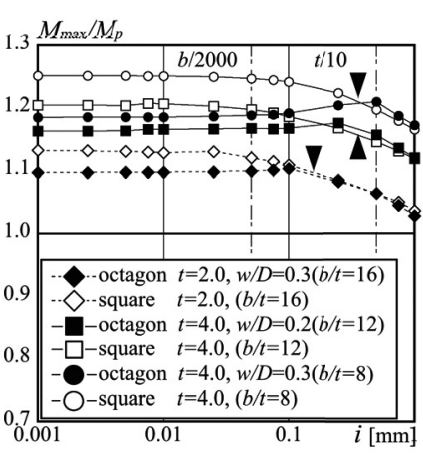

(a) Maximum Strength

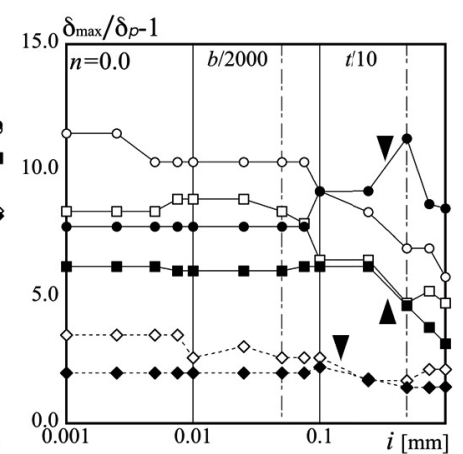

(b) Plastic Deformation Capacity

Fig.16 Effect of Initital Imperfection

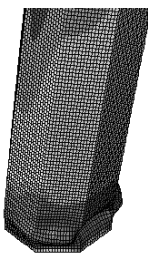

(a) $i=0.25$

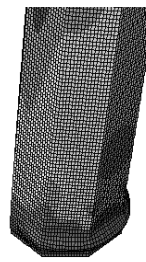

(b) $i=0.1$

Octagon, $t=2.0$ $w / D=0.3(b / t=16)$

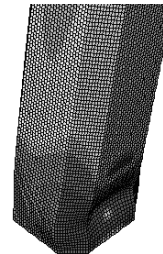

(c) $i=0.5$

Octagon, $t=4.0$ $w / D=0.2(b / t=12)$

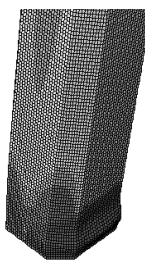

(d) $i=0.25$

(e) $i=0.001$ Square $t=2.0, b / t=16$

Fig.17 Effect of Initial Imperfection on Deformed Configuration Deformation 
八角形中空断面の変形形状は $i$ によ変化する，その変化点を で表す。この変化点よりもiが大きい場合にはFig.17(a), (c)のように 平板部のみが内側に凸となる変形形状が現れ, 八角形中空断面と同 幅厚比の正方形中空断面の最大耐力と塑性変形倍率は共に概放一致 する. 一方で変化点より を巻き込み全体が外側に凸となる変形形状が現れ，八角形中空断面 の最大耐力と塑性変形倍率は同幅厚比の正方形中空断面より小さく なる. 正方形中空断面はFig.17(e)のようにiが変化しても圧縮側フ

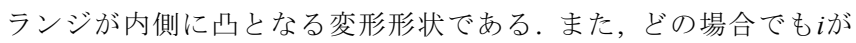
$b / / 2000$ より小さい範囲では最大耐力, 塑性変形倍率は概ね一定であ る.

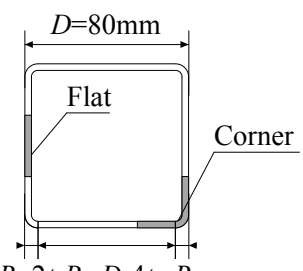

$R=2 t B=D-4 t \quad R$

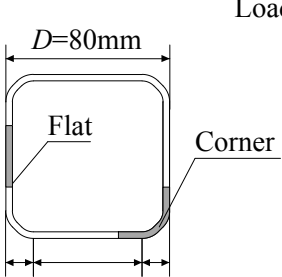

$3 t \quad B=D-6 t 3 t$

(a) Section
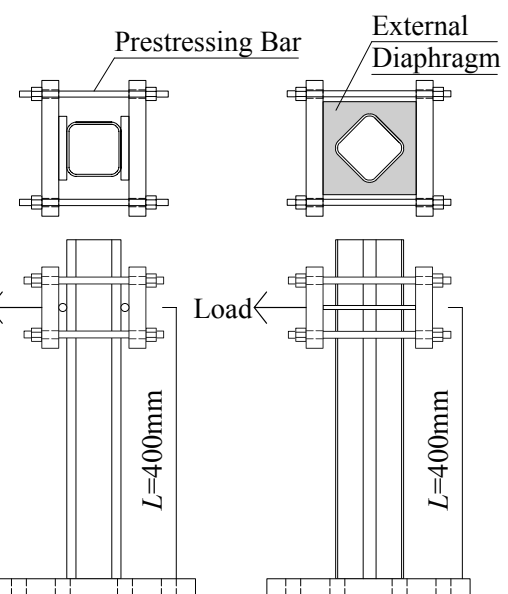

(b) $\alpha=0^{\circ}$

(c) $\alpha=45^{\circ}$
Fig.18 Schematic View of Bending Shear Test

Table 1 Specimen Parameter

\begin{tabular}{|c|c|c|c|c|c|c|}
\hline Section & Angle & Loading History & $t[\mathrm{~mm}]$ & $D[\mathrm{~mm}]$ & $B[\mathrm{~mm}]$ & $L[\mathrm{~mm}]$ \\
\hline \multirow{10}{*}{ Square } & \multirow{2}{*}{$0^{\circ}$} & Monotonic & 2.12 & 79.5 & 72.4 & 399.5 \\
\hline & & Cyclic & 2.14 & 79.7 & 71.2 & 399.5 \\
\hline & \multirow{2}{*}{$45^{\circ}$} & Monotonic & 2.11 & 79.5 & 72.3 & 399.7 \\
\hline & & Cyclic & 2.12 & 79.8 & 72.3 & 399.5 \\
\hline & \multirow{2}{*}{$0^{\circ}$} & Monotonic & 3.05 & 79.6 & 68.1 & 399.3 \\
\hline & & Cyclic & 3.01 & 79.5 & 68.2 & 399.5 \\
\hline & \multirow{2}{*}{$45^{\circ}$} & Monotonic & 3.02 & 79.9 & 68.1 & 399.5 \\
\hline & & Cyclic & 3.03 & 79.5 & 68.1 & 399.3 \\
\hline & $0^{\circ}$ & Monotonic & 4.18 & 79.8 & 64.4 & 399.0 \\
\hline & $45^{\circ}$ & Monotonic & 4.19 & 79.7 & 64.3 & 399.2 \\
\hline \multirow{8}{*}{ Octagon } & \multirow{2}{*}{$0^{\circ}$} & Monotonic & 2.37 & 79.6 & 68.1 & 399.3 \\
\hline & & Cyclic & 2.36 & 79.9 & 68.1 & 399.5 \\
\hline & \multirow{2}{*}{$45^{\circ}$} & Monotonic & 2.36 & 79.8 & 68.3 & 399.3 \\
\hline & & Cyclic & 2.35 & 79.6 & 68.2 & 399.7 \\
\hline & \multirow{2}{*}{$0^{\circ}$} & Monotonic & 3.27 & 79.9 & 62.3 & 399.5 \\
\hline & & Cyclic & 3.28 & 79.7 & 62.2 & 399.3 \\
\hline & \multirow{2}{*}{$45^{\circ}$} & Monotonic & 3.27 & 79.5 & 62.1 & 399.7 \\
\hline & & Cyclic & 3.27 & 79.5 & 62.0 & 399.5 \\
\hline
\end{tabular}

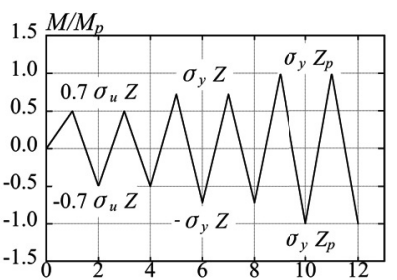

(a) First Term

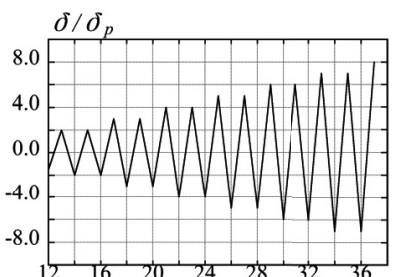

(b) Second Term
Fig.19 Introduction of Cyclic Bending Shear Test

\section{4. 曲げせん断力を受ける八角形中空断面部材の載荷実験}

Fig.18(a)のような削ぎ幅 $2 t$ または $3 t$ の二種類の角形鋼管部材に対 して，Fig.18(b)，(c)に示すように片持ち梁形式の曲げせん断試験を 行った。試験体はパラメータを断面形状, 板厚, 加力角度, 載荷履 歴とした単調試験体 10 体, 繰返し試験体 8 体とした。試験体一覧を Table1に示す。ここで，STKR400 N/mm²の角形鋼管部材の試験は 同じ全幅をもつ八角形中空断面部材との比較に用いている．試験体 は全て $400 \mathrm{~N} / \mathrm{mm}^{2}$ 級の冷間成形部材とした。繰返し載荷の履歴を Fig.19に示す. 繰返し載荷実験結果を単調載荷実験結果と比較する 際は荷重更新点を結んだ骨格曲線に変換した。なお，繰返し載荷の 荷重変位関係は，付録Bに示している。た鋼材の機械的性質は塑性 加工により断面内で異なる性質を示すため, Fig.18(c)に示す平板部 と角部の二箇所の引張試験を行った。引張試験結果の応力度ひずみ 度関係は全てラウンド八ウス型の曲線であり，降伏応力度は $0.2 \%$ 才

Table 2 Mechanical Property of Steel

\begin{tabular}{|c|c|c|c|c|c|c|c|}
\hline Section & $t[\mathrm{~mm}]$ & Location & $E\left[\mathrm{~N} / \mathrm{mm}^{2}\right]$ & $\sigma_{\mathrm{y}}\left[\mathrm{N} / \mathrm{mm}^{2}\right]$ & $\sigma_{\mathrm{u}}\left[\mathrm{N} / \mathrm{mm}^{2}\right]$ & Y.R. [\%] & $\varepsilon_{\mathrm{u}}[\%]$ \\
\hline \multirow{6}{*}{ Square } & \multirow{2}{*}{2.3} & Flat & $2.05 \times 10^{5}$ & 387 & 444 & 87.1 & 18.2 \\
\hline & & Corner & $1.85 \times 10^{5}$ & 389 & 461 & 84.4 & 4.64 \\
\hline & \multirow{2}{*}{3.2} & Flat & $2.05 \times 10^{5}$ & 385 & 447 & 86.2 & 16.2 \\
\hline & & Corner & $1.84 \times 10^{5}$ & 416 & 479 & 86.8 & 3.87 \\
\hline & \multirow{2}{*}{4.5} & Flat & $2.05 \times 10^{5}$ & 416 & 449 & 92.7 & 12.7 \\
\hline & & Corner & $1.82 \times 10^{5}$ & 438 & 483 & 90.7 & 3.63 \\
\hline \multirow{4}{*}{ Octagon } & \multirow{2}{*}{2.3} & Flat & $2.08 \times 10^{5}$ & 425 & 461 & 93.4 & 7.58 \\
\hline & & Corner & $2.11 \times 10^{5}$ & 382 & 424 & 90.1 & 2.69 \\
\hline & \multirow{2}{*}{3.2} & Flat & $2.01 \times 10^{5}$ & 418 & 448 & 92.3 & 3.76 \\
\hline & & Corner & $2.07 \times 10^{5}$ & 403 & 432 & 93.3 & 2.96 \\
\hline
\end{tabular}

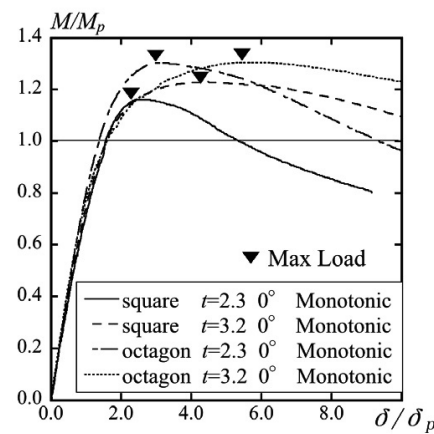

(a) Effect of Thickness and Shape

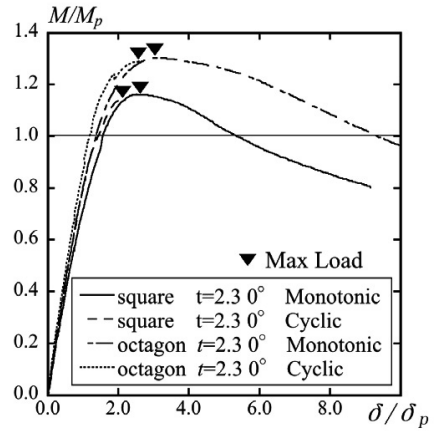

(c) Effect of Cyclic Load and Shape

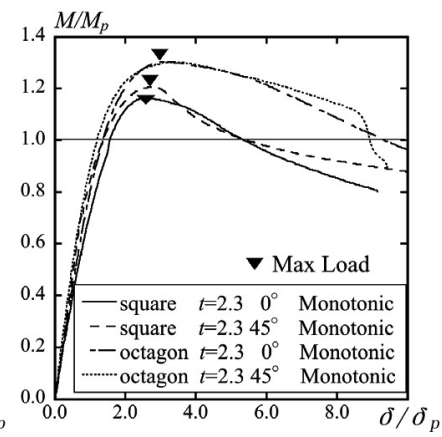

(b) Effect of Angle and Shape

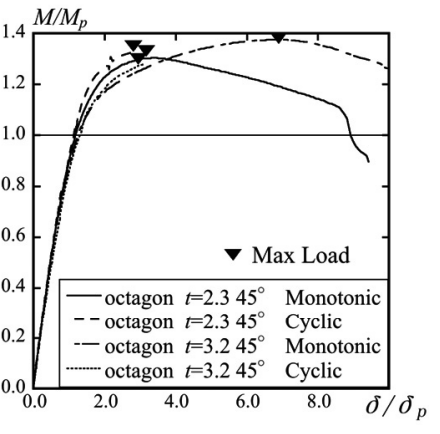

(d) Effect of Cyclic Load and Angle (Octagon )
Fig.20 Effect of Each Parameter on Deformation Behavior 


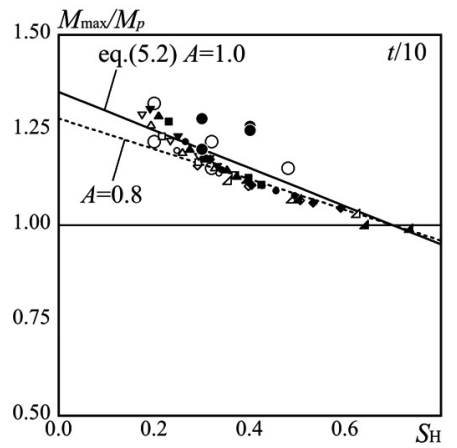

(a) Maximum Strength $i=t / 10$

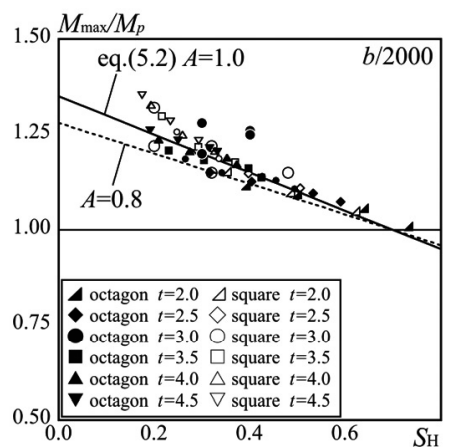

(c) Maximum Strength $i=b / 2000$

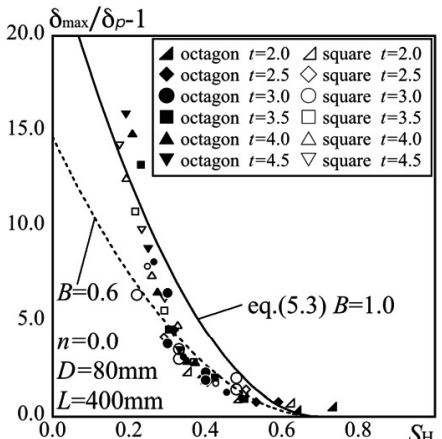

(b) Plastic Deformation Capacity $i=t / 10$

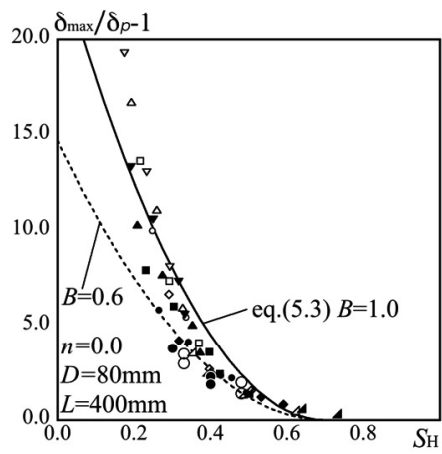

(d) Plastic Deformation Capacity $i=b / 2000$
Fig.21 Effect of Initial Imperfection on Maximum Strength and Plastic Deformation Capacity

フセット法により求めた。引張試験により得られた鋼材の機械的性 質を Table 2 に示寸. ここで $E$ : 弾性係数， $\sigma_{y}$ : 降伏応力度， $\sigma_{u}$ : 最 大引張応力度, Y.R.: 降伏比, $\varepsilon_{u}$ : 一様伸びである. Fig.20に曲げせ ん断試験の各パラメータの影響を示す. 以下の荷重変位関係は縦軸 を全塑性モーメント $M_{p}$, 横軸を $M_{p}$ に対応する弾性変位 $\delta_{p}$ で無次 元化している. また， $M_{p}$ は断面全体に平板部の降伏応力度 $\sigma_{y}$ を用 いて算出している. Fig.20(a)に板厚と形状が塑性変形性能に与える 影響を示す. 同板厚で比較すると八角形中空断面の塑性変形性能が 角形鋼管のものより優れていることがわかる. Fig.20 (b)に加力角度 と形状による影響を示す. 角形鋼管は 45 度方向載荷の方が最大耐 力は大きくなるのに対し，八角形中空断面は加力角度による影響が 小さい. Fig.20(c)に 0 度方向載荷の形状, 繰返し載荷の影響を示寸. 図から角形鋼管，八角形中空断面ともに繰返し載荷の影響で塑性変 形性能が低下寸ることがわかる. Fig.20(d)に 45 度方向載荷の八角 形断面の板厚, 繰返し載荷の影響を示す. 板厚が大きくなると繰返 し載荷の影響で塑性変形能力は大幅に低下している.

\section{5. 八角形中空断面部材の塑性変形性能評価}

本章では，大変形解析および載荷実験によって確認した八角形中 空断面部材の塑性変形性能の評価手法を検討寸る。

式(2.14)で表される曲げを受ける八角形中空断面部材の座屈係数 評価式を適用した文献2)による新規幅厚比尺度を式(5.1)に示寸。こ こで $\bar{k}$ を $k_{\mathrm{cr}}$ とおくことで八角形中空断面部材の新規幅厚比尺度と している.

$$
S_{\mathrm{H}}=\sqrt{\frac{M_{p c}}{M_{c r}}}=\sqrt{\frac{\sigma_{y}}{{ }_{b} k_{c r} \frac{\pi^{2} E}{12\left(1-v^{2}\right)}\left(\frac{t}{b}\right)^{2}} \frac{Z_{p}}{Z}}
$$

ここで $Z_{\mathrm{p}}$ : 塑性断面係数, $Z$ : 断面係数, $\sigma_{y}$ : 降伏応力度である.

式(5.1)で表される八角形中空断面部材の新規幅厚比尺度と大変 形解析結果および本実験結果により得られる最大耐力および塑性変 形倍率の関係をFig.21に示寸. 本実験結果は大きいプロットで示し, 黒いプロットが八角形中空断面，白いプロットが正方形中空断面の

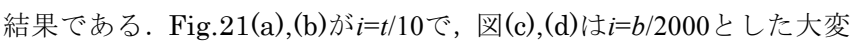
形解析結果を示している. 文献2)による最大耐力, 塑性変形倍率評 価式はそれぞれ式(5.2)，式(5.3)で表される。

$$
\begin{aligned}
& \frac{M_{\max }}{M_{p c}}=-0.5 A\left(S_{H}-0.7\right)+1.0 \\
& \frac{\theta_{\max }}{\theta_{p c}}-1=50 B\left(S_{H}-0.7\right)^{2}
\end{aligned}
$$

ここで $M_{\mathrm{pc}}$ ：軸力を考慮した全塑性モーメント， $\theta_{\mathrm{pc}}$ ：軸力を考慮し た弾性仮定の場合の全塑性モーメント時変位である.

式(5.2), 式(5.3)で表される新規幅厚比尺度による評価式を図に実 線で示す.ここで $A=B=1.0$ として表される．最大耐力に関して実験 結果は安全側に評価できているが，解析結果は安全側に評価できて いない， $A=0.8$ を式(5.2)に用いて修正した式を点線で示す．修正值 を用いることで初期不整によらず最大耐力を安全側に評価可能であ る. 塑性変形倍率に関して実験結果, 解析結果共に危険側に位置し てるプロットが多い. $B=0.6$ を式(5.3)に用いて修正した式を点線で 示す.この時,解析または実験結果を修正式で割った值の最低值は, 最大耐力については 0.81 , 塑性変形倍率については0.72であった， また, 解析または実験結果を修正式で割った值が1.0を下回る検討対 象割合は初期不整の大きい $i=t / 10$ の場合，最大耐力では $17 \%$, 塑 性変形倍率では $33 \%$ ，一方で初期不整の小さい $i=b / 2000$ の場合, 最大耐力では $4.2 \%$, 塑性変形倍率では $8.3 \%$ でる. 修正值を用いる ことで大変形解析, 本実験結果ともに概ね安全側に評価可能である.

\section{6. 結}

本研究では，純圧縮または曲げを受ける八角形中空断面部材を対 象とし，正方形から角を削ぐことが座屈係数に与える影響を，有限 要素法を用いて確認した。また軸力および曲げせん断力を受ける八 角形中空断面部材の塑性変形性能を, 同平板部長さをもつ正方形中 空断面部材のものと比較した。 その際部材長による影響を検討した. 次に初期不整が八角形中空断面部材の塑性変形性能に与える影響を 検討したそそして曲げせん断力を受ける八角形中空断面部材の塑性 変形性能を載荷実験によって確認し, 同全幅および同部材長をもつ 正方形中空断面部材の塑性変形性能と比較した．大変形解析による 結果と本実験結果を用いて八角形中空断面部材の塑性変形性能が新 規幅厚比尺度を用いた評価式により評価可能であるかを検討した． 以下に本研究で得られた知見を示す。

1) 純圧縮力を受ける場合，文献9)で提案されている座屈係数評価 式は文献9)では検討されていなかった板厚の範囲においても適 用できることを確認した。

2) 等曲げを受ける場合の座屈係数評価式について, 文献1)で提案 されている座屈係数評価式を利用した上で，さらに精度の高い 
評価式を提案し，解析值との対応を確認した。

3) 軸力および曲げせん断力を受ける八角形中空断面部材をその角 の削ぎ幅を大きくすることにより, 平板部の幅厚比が小さくな ることで最大耐力と塑性変形能力は上昇した.

4) 初期不整量が $t / 10$ の時, 八角形中空断面部材の平板部の幅厚比 と等しい幅厚比を持つ正方形中空断面部材の塑性変形性能は, 軸 力比や板厚によらず八角形中空断面部材のものと等しいことを 示した。一方で, 八角形中空断面部材のせん断スパン比が小さく なるとその傾向は見られないことを示した。

5) 八角形中空断面部材の平板部の幅厚比が等しい幅厚比を持つ正 方形中空断面部材の塑性変形性能が, 板厚によらず八角形中空断 面部材のものと等しいという傾向は, $t / 10$ よりも大きい初期不整 量の時に，成り立つことを示した。

6) 載荷実験により, 曲げせん断力を受ける八角形中空断面部材の塑 性変形性能は, 全幅と部材長が等しい正方形中空断面部材のもの 以上の性能を持つことを確認した.

7) 大変形解析および載荷実験の結果から, 正方形中空断面部材に 用いられる塑性変形性能評価式の係数を修正することで八角形 中空断面部材に適用可能であることを確認した。

\section{謝辞}

本研究を行うにあたり，日鉄建材 (株)様よりご支援，ご助言いた だきました。また本論文は元東京工業大学大学院生和田直大氏の研 究成果を整理し，構成しております，付して感謝いたします．

\section{参考文献}

1) Kosuke SATO, Kikuo IKARASHI, EVALUATION OF COUPLED LOCAL BUCKLING STRENGTH OF SQUARE HOLLOW SECTION MEMBER UNDER BIAXIAL BENDING SHEAR FORCE AND AXIAL FORCE, Journal of Structural and Construction Engineering (Transactions of AIJ), Vol.79, No.706, pp.1909-1918, 2014.12(in Japanese)

佐藤公亮, 五十嵐規矩夫 : 二軸曲げせん断力と軸力を受ける正方形断面 部材の連成局部座屈耐力算定，日本建築学会大会構造系論文集，第 706 号, pp.1909-1918, 2014.12

2) Kosuke SATO, Kikuo IKARASHI, LOCAL BUCKLING BEHAVIOR AND EVALUATION METHOD FOR STRUCTURAL PERFORMANCE OF SQUARE HOLLOW SECTION MEMBERS UNDER BENDING SHEAR FORCE, Journal of Structural and Construction Engineering (Transactions of AIJ), Vol.82, No.731, pp.123-133, 2017.1(in Japanese)

佐藤公亮, 五十嵐規矩夫 : 曲げせん断力を受ける正方形中空断面部材の 局部座屈性状と構造性能評価法, 日本建築学会構造系論文集, 第 731 号, pp.123-133, 2017.1

3) Kazuya MITSUI, Atsushi SATO, EXPERIMENTAL STUDY ON DEFORMATION CAPACITY OF SQUARE STEEL TUBULAR COLUMNS UNDER CONSTANT AXIAL FORCE WITH BENDING MOMENT, Journal of Structural Engineering, Vol.62B, pp.433-440, 2016.3(in Japanese)

三井和也，佐藤篤司：一定軸力下で曲げモーメントを受ける角形鋼管柱 の塑性変形能力に関する実験的研究,構造工学論文集, 第 $62 \mathrm{~B}$ 号, pp.433-440, 2016.3

4) Nobuhiro KOSETA, KOSETA, Tetsuhiko AOKI, Yuhshi FUKUMOTO: AN EXPERIMENTAL STUDY ON THE LOCAL BUCKLING STRENGTH OF STEEL OCTAGONAL SECTION STUB COLUMNS, Proceedings of the Japan Society of Civil Engineers, No.330, pp.27-36, 1983.2

小瀬古信博, 青木徹彦, 福本晴士 : 八角形断面鋼柱の局部座屈強度に関 する実験的研究，土木学会論文報告集，第 330 号，pp.27-36，1983.2

5) Yasuhiro MIGITA, KOSETA, Tetsuhiko AOKI, Yuhshi FUKUMOTO: AN EXPERIMENTAL STUDY ON THE LOCAL BUCKLING STRENGTH OF STEEL POLYGONAL SECTION STUB COLUMNS, Proceedings of the Japan
Society of Civil Engineers, No.422, pp.255-263, 1990.10 右田泰弘，青木徹彦，福本晴士：多角形断面鋼柱の局部座屈強度に関寸 る実験的研究, 土木学会論文報告集, 第422 号, pp.255-263, 1990.10

6) Ahmed Godat, Frederic Legeron, DieuDonneBazonga : Stability Investigation of Local Buckling Behavior of Tubular Polygon Columns under Concentric Compression, Thin-Walled Structures 53, pp.131-140, 2012

7) Tomoki KOBASHI, Nariaki NAKAYASU, Nobutaka SHIMIZU, Kikuo IKARASHI: LOCAL BUCKLING STRENGTH OF UNIFORMLY COMPRESSED OCTAGONAL THIN WALLED SECTION MEMBERS, Journal of Structural and Construction Engineering (Transactions of AIJ), Vol.82, No.735, pp.713-722, 2017.5(in Japanese)

小橋知季, 中安誠明, 清水信孝, 菅野良一, 五十嵐規矩夫 : 軸圧縮力が作 用する薄肉八角形断面部材の局部座屈耐力, 日本建築学会構造系論文集, 第 735 号, pp.713-722, 2017.5

8) Architectural Institute of Japan: Design Standard for Steel Structures - Based on Allowable Stress Concept -, 2005.9 (in Japanese) 日本建築学会 : 鋼構造設計規準 - 許容応力度設計法 - , 2005.9

9) Tomoki KOBASHI, Kikuo IKARASHI, Nobutaka SHIMIZU: ELASTIC LOCAL BUCKLING STRENGTH AND MAXIMUM STRENGTH OF RECTANGULAR SECTION MEMBERS WHICH WERE LOADED COMPRESSION AND BENDING, Journal of Structural and Construction Engineering (Transactions of AIJ), Vol.84, No.755, pp.97-107, 2019.1(in Japanese)

小橋知季，五十嵐規矩夫，清水信孝：曲げと圧縮が作用する薄肉長方形断 面部材の弾性局部座屈耐力及び最大耐力, 日本建築学会構造系論文集, 第 755 号, pp.97-107, 2019.1

10) Kobashi TOMOKI, Masaaki NAKAYASU, Nobutaka SHIMIZU, Yoshimichi KAWAI : A study on the effect of mutual restraint between adjacent plate elements on elastic buckling strength of members, Summaries of Technical Papers of Annual Meeting, Architectural Institute of Japan, Structures-III, pp.943-944, 2015.7(in Japanese)

小橋知季, 中安誠明, 清水信孝, 河合良道: 隣接する板要素の相互拘束 が部材の弾性座屈強度に及ぼす影響についての考察, 日本建築学会大会 学術講演梗概集, 構造-III, pp.943-944, 2015.7

11) Architectural Institute of Japan: Structural Steelwork Specification for Building Construction JASS6, 2018.1 (in Japanese)

日本建築学会 : 建築工事標準仕様書 JASS6 鉄骨工事, 2018.1

\section{付録 A}

Fig.A1 に実験と解析の対応を示す. 試験体は八角形中空断面部材の $t=2.3 \mathrm{~mm}$, 加力角度 0 度, 単調載荷のものを示している.

解析条件は，初期不整として圧縮側の板に凹みが出るようなモードの最小 次モードの変形の最大值が $t / 10$ となるように入力している．また，初期不整 として入力した一次モードを Fig.A2 に示す. また材料の応力度ひずみ度関係 は実験から得られた平板部のデータを断面全体に用いている.

付録 $\mathrm{B}$

Fig.B1，B1 に繰返し載荷を受ける角形鋼管部材，八角形中空断面部材の 繰返し荷重変位関係を示す.

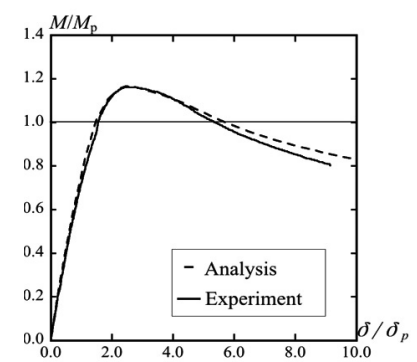

Fig.A1 Correspondence Between Analysis and Experiment

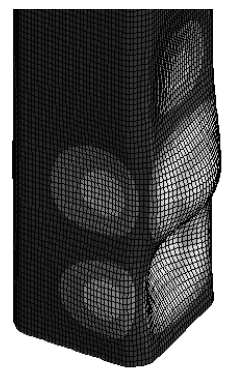

Fig.A2 Buckling Mode 


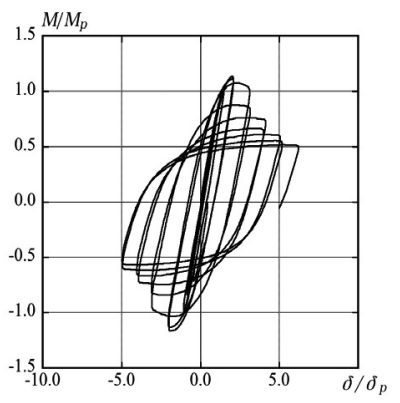

(a) Square Thickness $=2.3 \mathrm{~mm}$ Angle of Applied Force 0 deg

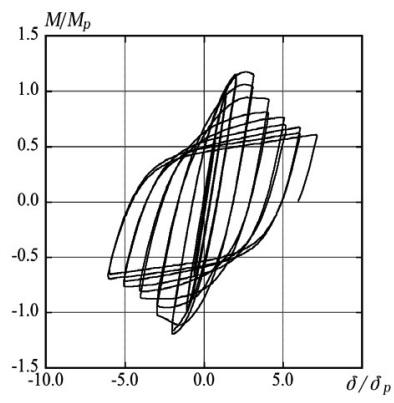

(b) Square Thickness $=2.3 \mathrm{~mm}$ Angle of Applied Force $45 \mathrm{deg}$

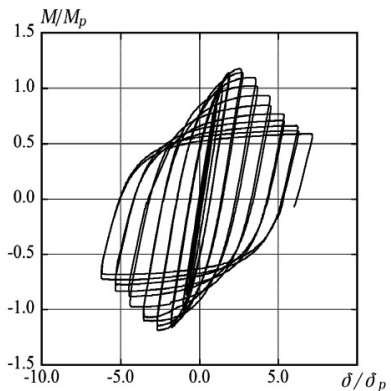

(c) Square Thickness $=3.2 \mathrm{~mm}$ Angle of Applied Force 0 deg

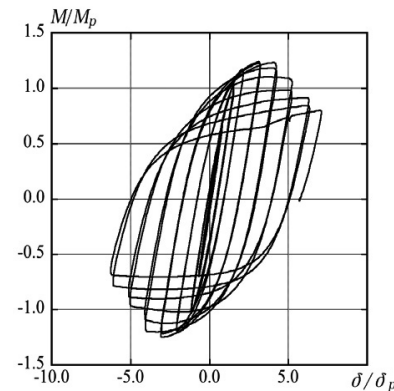

(d) Square Thickness $=3.2 \mathrm{~mm}$ Angle of Applied Force $45 \mathrm{deg}$

Fig.B1 Relation Between Normalized Bending Moment and Normalized Deformation (Square)

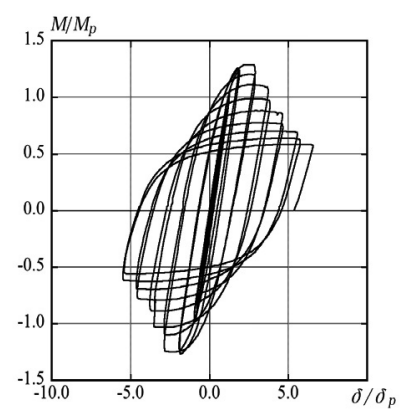

(a) Octagon Thickness $=2.3 \mathrm{~mm}$ Angle of Applied Force 0 deg

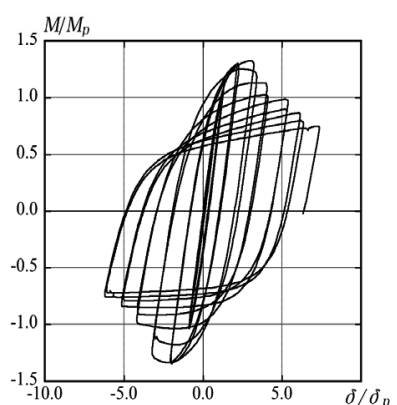

(b) Octagon Thickness $=2.3 \mathrm{~mm}$ Angle of Applied Force $45 \mathrm{deg}$

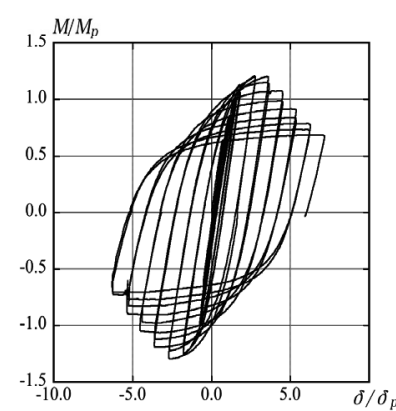

(c) Octagon Thickness $=3.2 \mathrm{~mm}$ Angle of Applied Force 0 deg

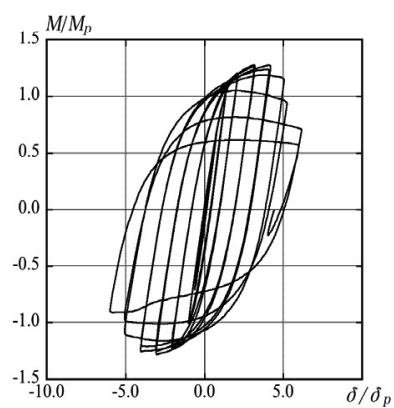

(d) Octagon Thickness $=3.2 \mathrm{~mm}$ Angle of Applied Force 45 deg

Fig.B2 Relation Between Normalized Bending Moment and Normalized Deformation (Octagon) 


\title{
EVALUATION OF PLASTIC DEFORMATION CAPACITY OF OCTAGONAL HOLLOW CROSS-SECTION MEMBER
}

\author{
Kikuo IKARASHI ${ }^{* 1}$ and Shu HACHIUMA*2 \\ ${ }^{* 1}$ Prof., Dept. of Arch. and Build. Eng., Tokyo Institute of Technology, Dr.Eng. \\ ${ }^{* 2}$ Grad. Student, Dept. of Arch. and Build. Eng., Tokyo Institute of Technology
}

A square hollow section member is generally used as a column in steel structures. Local buckling is known to affect the large deformation behavior. Local buckling is more likely to occur when the width-thickness ratio of the plate elements is large. Therefore, an octagonal cross sectional member that can reduce the width-thickness ratio of the plate elements and reduce the material is expected to be column.

Although there have been many previous studies on octagonal cross sectional members, none have examined the inelastic behavior of octagonal cross sectional members subjected to shear bending. In this study, the plastic deformation capacity of an octagonal cross sectional member subjected to shear bending is clarified based on the actual behavior of the member, and an evaluation method is proposed.

In this study, the buckling coefficient of an octagonal cross sectional member under compression or bending is calculated by eigenvalue analysis using the finite element method, and a buckling coefficient evaluation formula for octagonal cross sectional members under compression or bending is proposed.

In addition, the plastic deformation capacity of the octagonal cross sectional members was confirmed by the large deformation analysis of the cantilevered column form under axial and bending shear forces for the octagonal cross sectional members. In the comparison, the effect of the length of both members on the large deformation behavior was studied, and the plastic deformation capacity was investigated using a square hollow section member with the same thickness-width ratio of the plates. Next, in order to investigate the effect of the maximum value of initial imperfections on the plastic deformation capacity, a large deformation analysis is performed using the maximum value of initial imperfections as a parameter.

In order to understand the actual behavior of the octagonal cross section members, the plastic deformation capacity of the octagonal cross section members was confirmed by cantilevered bending shear tests and compared with the plastic deformation capacity of the square cross section members with equal width and length.

The buckling coefficient evaluation formula for octagonal cross section members obtained in this study is applied to the new width-thickness ratio for square cross-section members proposed in Reference 2), and the plastic deformation capacity evaluation formula using the new width-thickness ratio for square cross section members proposed in this study is examined whether it is possible to evaluate the plastic deformation performance of octagonal cross section members obtained by large deformation analysis and loading tests. The effect of the initial imperfection on the plastic deformation capacity of the square and octagonal cross section members is taken into account. 